Snejana UNG

Faculty of Letters, History and Theology, West University of Timişoara

Timişoara, Romania

snejana_ung@yahoo.com

\title{
CROSSING BORDERS: \\ FROM (EX-)YUGOSLAVIA TO THE WHOLE WORLD
}

Recommended Citation: Ung, Snejana. "Crossing Borders: From (Ex-)Yugoslavia to the Whole World". Metacritic Journal for Comparative Studies and Theory 6.1 (2020): https://doi.org/10.24193/mjcst.2020.9.04

\begin{abstract}
Starting with the 1990s a myriad of literary texts that tackle the Yugoslav wars have been published worldwide. Despite the wide variety of texts, scholars (Obradović, Pisac, Vervaet, Wachtel) have focused mainly on those written by exYugoslav writers and on the representation of the former country in these books. This paper focuses on the aforementioned literary phenomenon - the representation of exYugoslavia - from a broader perspective. My selection includes texts that originate in different geo-cultural areas. In this respect, the aim of this paper is to show that former Yugoslavia is not the only space represented in this cluster of texts. Other countries and cities, such as Germany, Ukraine, Amsterdam, or Shanghai, also play a significant role. I argue that the occurrence of these various spaces reveals a paradoxical pattern: the closer to ex-Yugoslavia the writer is or was, the more diverse the fictional spaces are, as well as vice versa. However, this geo-cultural diversity that defines postYugoslav migrant writers is constantly disregarded by critics, cultural journalists, and scholars, which is an indication of the hegemonic character of world literature.
\end{abstract}

Keywords: world literature, ex-Yugoslavia, mapping literature, migrant literature, literary space, literary geography.

In the heyday of the emergent states that followed up the disintegration of Yugoslavia two types of literary systems pursued to struggle for dominating the post-Yugoslav literary space. On the one hand, there is the national model, which mirrors - at the literary level - the formation of new states. On the other hand, a transnational system 
called post-Yugoslav literature ${ }^{1}$ emerged too. It is this system - rather than the national ones - that gained worldwide recognition ${ }^{2}$. Not only is it coeval with the post-national paradigm in literary studies, but it is also relevant for the Yugoslav literary tradition. Transnational by its/their very nature, Yugoslav literature(s) 3 are the basis on which the so-called national literatures were created. It actually seems that post-Yugoslav literature is the natural and predictable outcome of the literary reconfigurations after the 1990s. In his article on the legacy of Danilo Kiš in post-Yugoslav literature, Andrew Wachtel claims that there is an undeniable relation between Yugoslav and postYugoslav literature: "For there to be a post-Yugoslav literature, there should have been a Yugoslav literature" (Wachtel, The Legacy 135). However, regardless of its global recognition as a proper term to define the literature that emerged after the Yugoslav wars - which can be interpreted as a result of the Western cultural hegemony, as I argue in this paper - there is no consensus on what kind of system the post-Yugoslav literature really is.

The terminological imprecision, along with the diversified literary production, led to a wide variety of literary practices. In the last two decades scholars have approached post-Yugoslav literature: 1) as war literature, by analysing the manner in which the Yugoslav wars are represented in literary works; 2) as migrant literature, by focusing on the theme of dislocation in the literary works written by ex-Yugoslav migrant writers; 3 ) in light of the temporal and literary nexus with Yugoslav literature and the legacy it left to the post-Yugoslav literature; 4) or as a wider phenomenon, by trying to inscribe it in the larger framework of world literature4. However, these approaches of post-Yugoslav literature are not applied per se. There are also interweavings between them. For example, the literary works written by post-Yugoslav

\footnotetext{
${ }^{1}$ See Andrew Wachtel, "The Legacy of Danilo Kiš in Post-Yugoslav Literature", The Slavic and East European (135-149) for the relations between on one hand post-Yugoslav literature and national literatures and, on the other hand, post Yugoslav literature and Yugoslav literature(s).

${ }^{2}$ I use worldwide recognition to refer to the higher visibility of the scholarly debates on post-Yugoslav literature. Besides conferences, there were published scholarly works which - due to the fact that they were written in English - reached a global scholarly audience. In my view, the worldwide recognition of the term is also determined by the success of the ex-Yugoslav migrant writers such as Dubravka Ugrešic and Aleksandar Hemon on the world-literary market.

3 For the differences between Yugoslav literature and Yugoslav literatures, see Andrew Baruch Wachtel, Making a Nation, Breaking a Nation: Literature and Cultural Politics in Yugoslavia, Stanford, Stanford University, 1998, and Marko Juvan, "The Invisible Other? Slovenian Comparative Literature and Yugoslav Literature" (63-78), Jugoslovenska književnost: prošlost, sadašnost I budućnost jednog spornog pojma, Belgrade, 2019.

4 See Stijn Vervaet, "Ugreišić, Hemon, and the Paradoxes of Literary Cosmopolitanism: or How to 'World' (Post-)Yugoslav Literature in the Age of Globalization" (161-169), Komparativna književnost: teorija, tumačenja, perspektive. Encompassing Comparative Literature: Theory, Interpretation, Perspectives, Belgrade, 2016.
} 
migrant writers can simultaneously fall in several categories because they fictionally explore the Yugoslav war, the experience of migration, and the interconnections between post-Yugoslavia and its Socialist past and literature.

I suggest that such an intertwining of approaches can contribute to a better understanding of what this transnational system can be. The first observation is that post-Yugoslav literature is coeval with and reflects not only the post-national shift and the Yugoslav legacy, but also the migration flows which are at the core of the sociopolitical changes. This leads me to the second observation, namely that the gesture of including migrant literature in the category of post-Yugoslav literature increases the possibility of inscribing this category of literary texts in the paradigm of world literature. This possibility implies a geospatial recalibration of post-Yugoslav literature, which is not anymore reduced to the newly emergent states but opens up to geo-cultural spaces external to the ex-Yugoslav space. From this point on, postYugoslav literature should be understood in both temporal and spatial terms. But the temporal and geographical coordinates manage to bring together while simultaneously dissociate the here-and-there, the now-and-then.

The discussion has focused so far on two types of literary systems - national and post-Yugoslav literature -, on the higher visibility of the transnational over the national, and on the complexity of post-Yugoslav literature. However, besides the increasing visibility of post-Yugoslav literature, I argue that the literature about former Yugoslavia thrives on the world literary market too. Based on thematic criteria, this system comprises literary works that tackle the Yugoslav wars from the 1990s, but originate outside the former country and are not necessarily written by ex-Yugoslav writers. In what follows I seek to show that such a literary phenomenon supports the hegemonic view on world literature. In this regard, I will start by using literary geography to explore how and what spaces and places are represented in this cluster of texts. The geography of this literature along with the geography in this literature is relevant when assessing the inequalities that still shape world literature and the distinctions between literary works of post-Yugoslav migrant writers - those who left Yugoslavia - and of writers originating in other countries.

In my view, there are several distinctions between post-Yugoslav migrant writers and those who originate in other parts of the world. Firstly, post-Yugoslav migrant writers bring together the war, the experience of migration, and the life in Socialist Yugoslavia while other authors focus almost exclusively on the war. Secondly, 
they have a wider circulation and visibility while authors from other countries are deemed to less if any visibility in the world-literary system. Thirdly, despite the fact that they are often categorized according to the newly formed states, post-Yugoslav migrant writers open up textually to the world by representing a multitude of cities and countries in their writings while those who focus mainly on the war display a less diversified internal geography.

\section{Geography of literature and thematic export}

Scholars of world literature have often manifested interest in literary geography. By far the most prominent name in the field is Franco Moretti. His Atlas of the European Novel, 180o-19oo brings to the fore two different types of literary geography. On the one hand, Moretti tackles the space in literature or, in other words, the internal geography of literary works. On the other hand, he visualizes the literature in space, which calls for a display of the real historical space (Moretti, Atlas 2). The double approach of the relationship of geography with literature makes Moretti's project influential for both the already established discipline of literary geography and the field of literary studies. As Peta Mitchell claims, "literary cartography has, since its inception, primarily been interested in maps in literature rather than maps of literature" (Mitchell 86). Thus, by focusing on both versions of literary geographies, Moretti challenged and extended the interdisciplinary boundaries between geography and literature, showing that the influence is not unidirectional but reciprocal.

Besides its interdisciplinary significance, the relevance of the Atlas resides in the methodology. Moretti does not use maps for their mere illustrative function. On the contrary, for Moretti maps are "analytical tools: that dissect the text in an unusual way, bringing to light relations that would otherwise remain hidden" (Moretti, Atlas 3). In his view, an effective map is one that leads the research to unforeseen questions and answers. Moreover, using mapping as method requires a step away from the traditional "close reading". By generating and analysing maps, scholars find themselves in the situation of interpreting data not texts. They replace, especially for a large corpus of texts, close reading with distant reading (Moretti, Conjectures 56-58). In his article "World Literature and Globalization", Eric Hayot sheds light on this methodological shift. He shows that system-oriented methods, such as those proposed by Franco Moretti and Pascale Casanova, are borrowed from social sciences, from fields of study that use quantitative methods (Hayot 224-225). However, world 
literature, argues Hayot in the very beginning of the same article, does not replace close reading with distant reading; the two ways of reading are, in fact, two modes in which world literature can appear (Hayot 223).

The spatial turn is another methodological shift that marked the literary studies. Broadly, this shift refers to the replacement of the national with the transnational. According to Marko Juvan, the methodological change the spatial turn brought in the literary studies "does not deny historicity tout court but only further elaborates methods of contextualization". Such methods include the area-based approaches to comparative literature, like Neubauer's and Cornis-Pope's History of the Literary Cultures of East-Central Europe (Juvan, Spatial Turn 86-87). This literary historiographic practice reminds of Dionyz Durišin's systemic theory of inter-literary communities and centrisms 5 , elaborated before the systemic models of world literature proposed by Franco Moretti and Pascale Casanova. However, no matter what type of systemic theory we refer to, both world literary studies and transnational literary historiography succeed in exceeding the national paradigm that dominated until the end of the twentieth century. The methodological changes facilitated by the spatial turn allow scholars to properly approach post-Yugoslav literature using the global frame of reference. But the question is how far beyond the borders can we go when approaching the literature about the former Yugoslavia?

As I stated previously, my aim is to show that the attempt to inscribe this literary system in the paradigm of world literature ${ }^{6}$ is conditional on the hegemonic character of Western culture. In this regard I selected a cluster of literary works that tackle the Yugoslav wars but that were written by authors who currently live outside the exYugoslav space. Moreover, with one exception, all the works were published outside this space as well. This exception is Dubravka Ugrešić's novel The Ministry of Pain (2004), which was published in Belgrade and Zagreb at the moment when Ugrešić was already living in Amsterdam7. For two other exceptions the country where the author lives do not juxtapose with the place of publication. The first exception is Aleksandar Hemon's Love and Obstacles (2009) which was published for the first time

\footnotetext{
5 See Dionýz Ďurišin, Theory of Interliterary Process, translated by Jessie Kocmanová and Zdeněk Pištek, Slovak Academy of Sciences, Bratislava, 1989.

${ }^{6}$ See Snejana Ung, "The Literature about Former Yugoslavia in the Paradigm of World Literature", 3842.

7 Unlike other writers who left Yugoslavia and adopted the language of the host country such as Saša Stanišić and Aleksandar Hemon, Dubravka Ugrešić writes her books in Croatian.
} 
simultaneously in Great Britain and the $\mathrm{USA}^{8}$. The second one is The Cellist of Sarajevo (2008), written by the Canadian author Steven Galloway and published for the first time in Australia. All the other literary works approached in this paper were printed in the country where the author was living at the time. These works are, as it follows: Dubravka Ugrešićs Museum of Unconditional Surrender (1997, Netherlands), Aleksandar Hemon's Nowhere Man (2002), The Lazarus Project (2008), and The Book of My Lives (2013, USA), Saša Stanišić's How the Soldier Repairs the Gramophone (2006, Germany), Clara Usón's The Daughter of the East (in original: La hija del Este, 2012, Spain), Orcsik Roland's Ghost-Commando (in original: Famtomkommandó, 2016, Hungary), and Radu Pavel Gheo's Disco Titanic (2016, Romania).

This limited, particularized cluster of texts consider only those post-Yugoslav literary works that circulate on the Romanian literary market either in translation or in original. Juvan's emphasis on the need to understand world literature as perspectivized becomes visible in this case. Pespectivization implies the existence of world literature in the plural, which means that every national literature has its own version of world literature based on its translation repertoires and canons (Juvan, "Perspectivizing..."). The same can be said regarding the literature about former Yugoslavia. The very selection of the cluster of texts shows that we deal with the Romanian version of the literature about former Yugoslavia. From the perspective of the Romanian literary market, the post-Yugoslav literary system includes texts originating both in central and peripheral geo-cultural areas. By contrast to the Western corpora9, this variant manages to include literary works that explore the theme of war in different thematic combinations: war and migration as well as war and peripheral spaces.

\footnotetext{
8 This situation can be explained by the mergers that occurred starting with the $1970 \mathrm{~s}$ in the publishing fields, when small, independent publishing houses were bought by transnational conglomerates.

For the changes in the publishing field see John Thompson, Merchants of Culture: The Publishing Business in the Twenty-First Century, Cambridge, Polity Press, 2011.

9 The different corpora are the result of the uneven circulation of the literature about former Yugoslavia. For instance, up to this moment neither Famtomkommandó nor Disco Titanic which deal - both with the Yugoslav war and the periphery of the periphery - Vojvodina in the former, Banat in the latter have been translated in English. Undoubtedly, the lack of translations can be the result of their peripherality but the situation becomes problematic when another example is considered. It is the case of Usón's novel, which, similar to Gheo's and Orcsik's, falls under the category of war literature and peripheral spaces. One would expect this novel to enjoy higher visibility on the world literary market due to the centrality of the literary market in which it originates. However, contrary to the expectations, its visibility is mainly reduced to the Romance-speaking world.
} 
The geography of post-Yugoslav literature allows to distinguish other forms of circulation flows. The second type of circulation derives from the overarching theme: the war. Even though all the aforementioned books were published in different countries, they can be considered part of the same group due to their common theme. Unlike the circulation of books, the circulation of theme follows a different path. In his analysis on the European novel, Franco Moretti found out that "movement from one periphery to another (without passing through a centre) is almost unheard of; that movement from the periphery to the centre is less rare, but still quite unusual, while that from the centre to the periphery is by far the most frequent" (Moretti, More Conjectures 75-76). Undoubtedly, the circulation flows of literary forms usually follow the last pattern as Moretti successfully proves it. I want to stress, however, that the thematic export in the case of post-Yugoslav literature goes from the periphery to the centre. The aforementioned publication years on the chronological axis are a clear evidence. The first to write about the former Yugoslavia are ex-Yugoslav migrant writers, as expected. Writers from major literatures follow them and, interestingly enough, the last to join this geography of post-Yugoslav literature are writers who live on the other side of the ex-Yugoslav border, namely in Hungary and Romania. Such a route of influence shows that "phenomena are driven from the centre to the periphery while, conversely, phenomena may push their way into the centre and occupy it" (EvenZohar 14). But can this movement overcome the inequalities that shape the worldliterary system or is it another mere symptom of the Western-centrism?

Although it opens up the former Yugoslav space to the entire globe, the thematic export can be perceived as a means of gaining recognition in a literary world that seeks exoticism or as a way to respond adequately to the literary consumption demand of the Western, hegemonic audience (Pisac 232-61). This demand consists of delivering "domesticated differences" and of making "easily digestible cultural differences" (Vermeulen 79). What we can also learn about former Yugoslavia from the thematic export and the geography of the literature is that such literary works constitute a "specialized niche market" (Apter 2006), which is facilitated by circumstances such as the Yugoslav wars, the rise of migration flows, and by the global demand for first-hand experiences. In what follows, I will show that post-Yugoslav migrant writers display in their literary works a highly diversified internal geography which is neglected because of the Western demand for exoticism. These authors are also the most visible in the world-literary system and are continually associated with the local horizon, that is, the 
vanished country, and the experience of migration. At the other extreme, there are the writers originating in other countries, who have a lower visibility, focus predominantly on the war and peripheral spaces, and display a less diverse internal geography.

\section{Framing the Local and the Global: Geography in Literature}

Franco Moretti begins his Atlas of the European Novel, 180o-19oo with the following statement: "Making the connection between geography and literature explicit, then mapping it: because a map is precisely that, a connection made visible - will allow us to see some significant relationships that have so far escaped us" (Moretti, Atlas 2). In this paper, I discuss the aspects in the literature about the former Yugoslavia that can be revealed by using maps as analytical tools.

I explored the extent to which the peripheral local is represented in this literary system by generating several maps. More precisely, I used cartography to visualize the literary space represented in the literature about former Yugoslavia. Firstly, I mapped the spaces where the action takes place. Secondly, I included other places that play a significant role in the novel or in characters' lives such as the places where parts of their family have lived or live. Yet I must acknowledge that these maps do not point out all the spaces mentioned in the literary works. One reason that prevented me from acknowledging all the spaces is that there is found a large number of countries and cities mentioned only once in the novels, which would have led to different maps. Another reason is that such countries and cities have an ornamental rather than a structural function, which means that they do not change the setting and plot of the novels.

My cartographical project comprises 11 literary works written by 7 authors and 28 cities fictionally represented in this cluster of texts (Map 1). However, based on the total sum, two aspects can be considered of extreme relevance: 1) the quantitative differences between the representations of post-Yugoslav space and those of other spaces and 2) the number and the geographical distribution of places in each author's writings.

As far as the fictional representation of ex-Yugoslavia is concerned, I noticed that 8 out of the distinct 28 points on the map are part of the former country; this means almost $30 \%$ of the total sum. Moreover, by far the most encountered city is Sarajevo, which is found in 6 of the 11 literary works analysed herein, followed by Zagreb, which appears only in 2 works. But why Sarajevo? Is it because of what 
Dragana Obradović calls "the spectacle of the siege" (Obradović 37)? Or are there other reasons? A first explanation refers to another quantitative problem: unlike other writers, who have no more than two works included in the analysis, Aleksandar Hemon has four and Sarajevo is the setting in each one.

Apart from this quantitative matter, a closer look at Hemon's and Galloway's books is extremely useful. I will start by emphasizing that Sarajevo from Hemon's writings is not only the besieged one. First and foremost, it is the city of his characters' youth, a city from the former socialist Yugoslavia, and also the hometown that was left behind. This wider chronological framework succeeds in bringing together two images of the city: Sarajevo as the most multicultural city of Yugoslavia and Sarajevo as the besieged city. On the opposite side, Galloway's The Cellist of Sarajevo is a novel that minutely describes the everyday lives of four characters - one of whom is the cellist Vedran Smailović, who played during the siege - and their fight for survival in the ruined city. By focusing on the long siege and its daily impact on the characters' lives, Galloway draws attention on the traumatic experiences during the wartime. Therefore, instead of the aestheticization of the war proposed by Obradović, I suggest that the constant presence of Sarajevo in the literature about former Yugoslavia is determined by the fact that Sarajevo is a symbol for both the "Balkan" otherness because of its multiculturalism, and for the Yugoslav war because of the long-lasting siege.

The aforementioned observations, along with the cartographical representation of the fictional spaces (Map 1 and Map 2) lead to the following hypothesis: the literary works concerned exclusively with the wartime may experience a geographical poverty while those that include different temporal frameworks may reflect a variety of geographies. The explanation should start from the following intriguing feature: the high numerical difference between the local post-Yugoslav space and the global. This time, 20 out of 28 places are from outside the ex-Yugoslav space, and their cartographical representation spans from Eastern to Western Europe, North America, Asia and Africa. Nonetheless, despite the high difference (more than 70\%), all these cities seem not to weigh too much in the critical reception of these books. One reason for this interpretative omission may be that authors coming from the peripheries are expected to provide images of the local. To paraphrase Damrosch, they are perceived rather as "windows of $a$ world" than "windows of the world" (15). Another reason may be the lower number of occurrences, as the maps indicate. The second most frequent city is Chicago, the other main setting in Hemon's writings, which appears in 4 literary 
works. The third in rank are Berlin, Kiev, and Hamilton (Canada), all of them appearing in 2 literary works, and all of them related to the experience of migration. The rest of 16 places can be found in only 1 of the total 11 works concerned in the analysis.

This overview provides essential information on the negotiations between the local and the global in the literature about former Yugoslavia. The dispersion of all 16 places in 11 writings asks for a closer look at every writer and his/her literary works. However, while mapping, I discovered similarities between some of the literary works, which allowed me to divide them in four groups, according to the geo-cultural region(s) they fictionally represent.

My research shows that the least diversified novels are Steven Galloway's The Cellist of Sarajevo and Orcsik Roland's Fantomkommandó [Ghost-Commando]. In the former, the action takes place in Sarajevo. In the latter, the action is set in an anonymous city situated close to the border with Hungary. The lack of cartographical precision puts the reader in the situation whereby s/he "will need to hunt for clues about location" (Piatti 184). However, thanks to the details given by the first-person narrator regarding the presence of multilingualism in the region, the reader can spot the equivalent of the narrative space in the actual world: the Serbian region of Vojvodina. Moreover, at some point "Bečej" town is mentioned and it is known that Bečej is actually a small city in Vojvodina region. Besides the fact that both novels are characterized by geographical poverty, both of them share another similarity: the action covers a short time-span, namely the wartime.

The third novel that can be inscribed in this category is Radu Pavel Gheo's. His novel is transnational by its very nature, as the action is set in the ex-Yugoslav space, mainly in Split, and in Timișoara (Romania). Compared with other novels, the setting is still limited. It covers only Eastern Europe (Map 3). But one should not forget that these places - Banat in Gheo's novel and Vojvodina in Orcsik Rokand's novel are, in fact, transnational and multicultural. Using John Neubauer and Marcel-Cornis Pope's concept of "marginocentric" nodes, Christian Moraru and Andrei Terian write that

What we witness in "marginocentric" nodes such as Romania's southwestern province of Banat or even in Romania as a whole, then, is not so much a complete collapse of the rigid centre-margin (Western-Eastern) binary but its "loosening". In turn, this allows for a stretching out of the cultural-historic fabric that, in a particular knot or node (Banat's 
main city of Timişoara, Banat itself, or Romania), "blows up" almost photographically and thus brings into view a complexity of texture, shape, and colour, a worldedness that, back at the "strong" artistic and academic centre (Vienna, Austria, Paris, or France), may be elusive, invisible, and, in extreme situations, inexistent. (Moraru and Terian 5)

Thus, everything that seemed local and peripheral so far is re-valued as trans-, multi-, and intercultural.

The next layer of literary works is represented by Clara Usón's and Saša Stanišić's novels, in which the geographies comprise cities from both Eastern and Western Europe (Map 4). The underlying pattern is 2 cities from Eastern Europe and 1 from Western Europe per each novel. Of course, the places in La Hija del Este are very much conditional on the genealogy of the novel. The novel tells the story of Ana Mladić, the daughter of the war criminal Ratko Mladić. She committed suicide after she came back from a trip to Moscow, where she found out the truth about her father. The story itself is marked by the presence of the two Eastern places found in Usón's novel: Belgrade and Moscow. The Western counterpart is represented by London, where Danilo Papo, the narrator and the main character of the second narrative framework, lives. On the other hand, the cities from How the Soldier Repairs the Gramophone follow the path of the writer's movements. Aleksandar Krsmanović's exile story reiterates Stanišić’s biography, who, in 1992, exactly like his character, fled from Višegrad to Germany.

I included Stanišić's novel in the same category with Usón's novel because of the results reflected in the cartographical data. Unlike in Hemon's and Ugrešić's writings, the representation of space in How the Soldier Repairs the Gramophone does not exceed the European boundaries. Moreover, even Hemon and Ugrešić need to be discussed separately, based again on the geographical criteria. But before this, I want to emphasize one main difference between the non-Yugoslav and post-Yugoslav migrant writers.

According to Damrosch, one of the definitions of world literature is that "world literature is an elliptical refraction of national literatures" (Damrosch 281). Such a definition seems to leave aside migrant writers, transnational literature and 


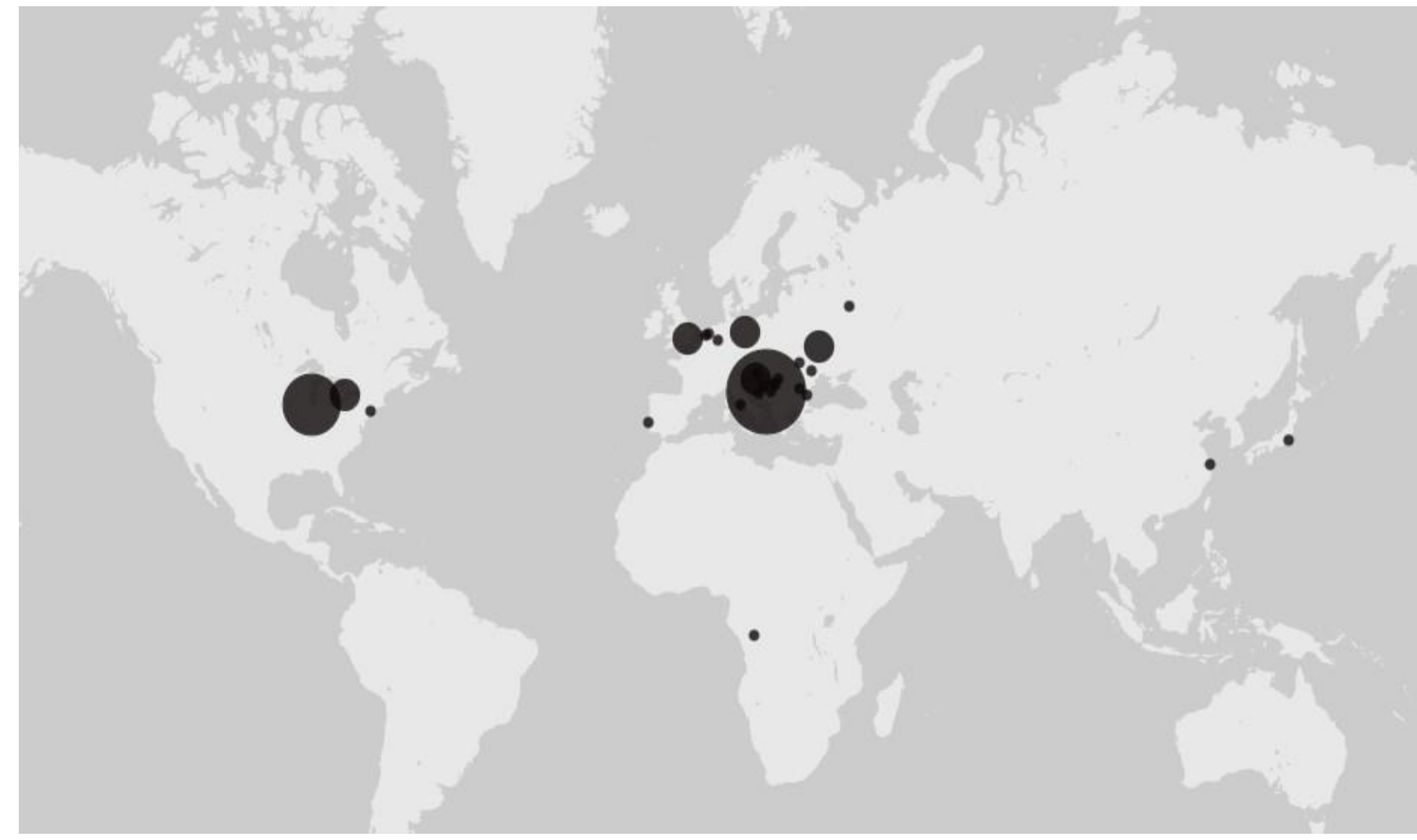

Map 1. Spaces in post-Yugoslav literature (Global framework)

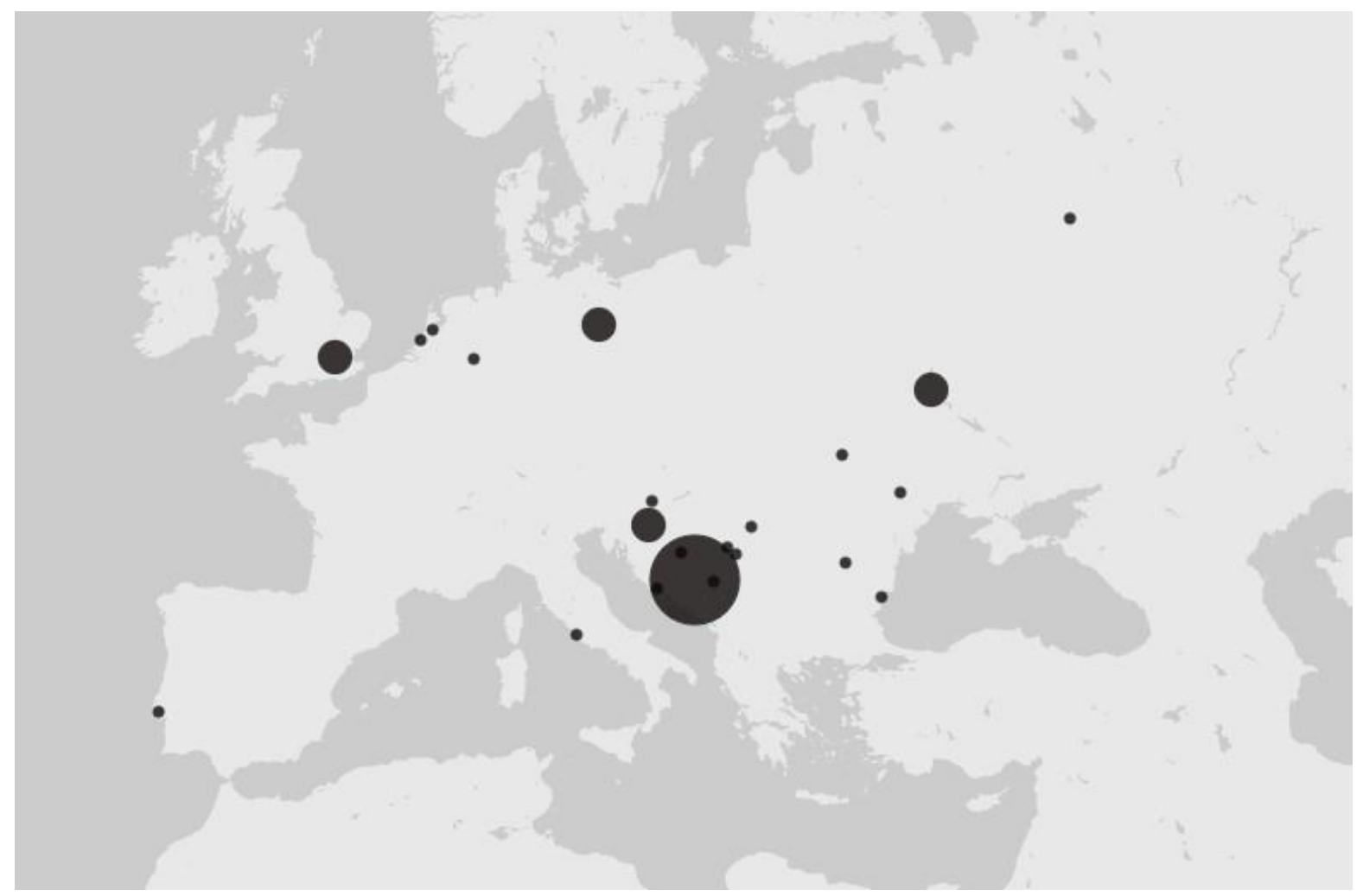

Map 2. Spaces in post-Yugoslav literature (European framework) 
"born translated" literature (Walkowitz 3). In Mapping World Literature, Mads Rosendahl Thomsen points out exactly these conceptual limits:

To what literary cultures do such writers belong, when they become detached from the literary culture and criticism to which they once belonged? Have they not been transformed from being writers belonging to a nation, to writers belonging more to the world, thus transcending the comparative aspect of comparative literature? (Thomsen 23)

Even though Thomsen takes the case of instantly translated authors as an example, the same questions can be addressed with regard to post-Yugoslav migrant writers as well. With this question in mind, I tried to find out if the mapping of post-Yugoslav spaces can help me provide a satisfactory answer. Interestingly enough, the spaces represented on the Map 5 and Map 6 show that Dubravka Ugrešićs and Aleksandar Hemon's writings could easily fall in the paradigm of migrant literature. As we can notice, 2 cities dominate the fictional geographies in their writings: Sarajevo and Chicago (in Hemon's) and Zagreb and Berlin (in Ugrešićs) - cities that coincide with those in which the writers and also their characters had lived or live. Thus, the mapping of space in literature shows that we deal with a transnational literature.

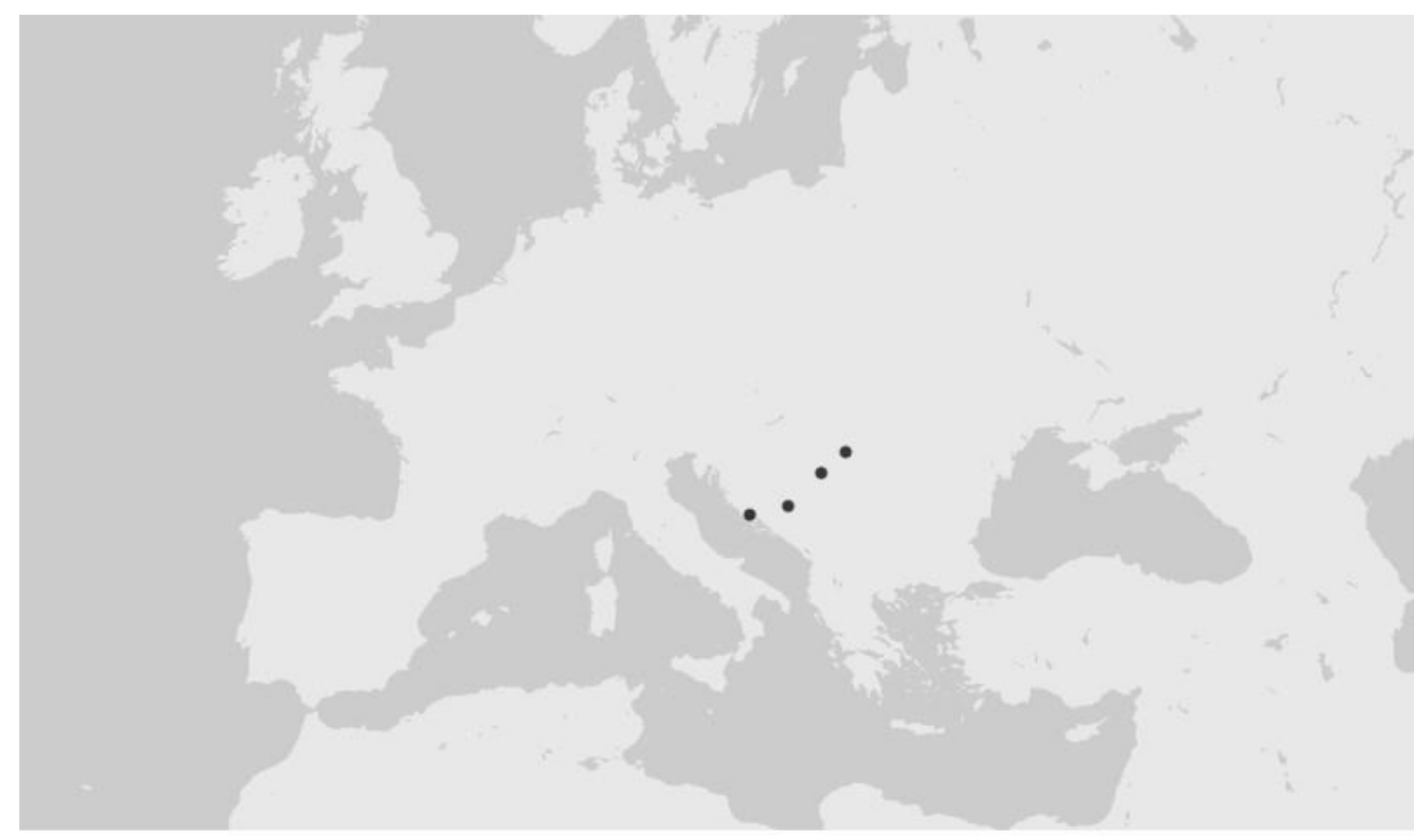

Map 3. Space in Orcsik Roland's, Steven Galloway's, and Radu Pavel Gheo's novels 


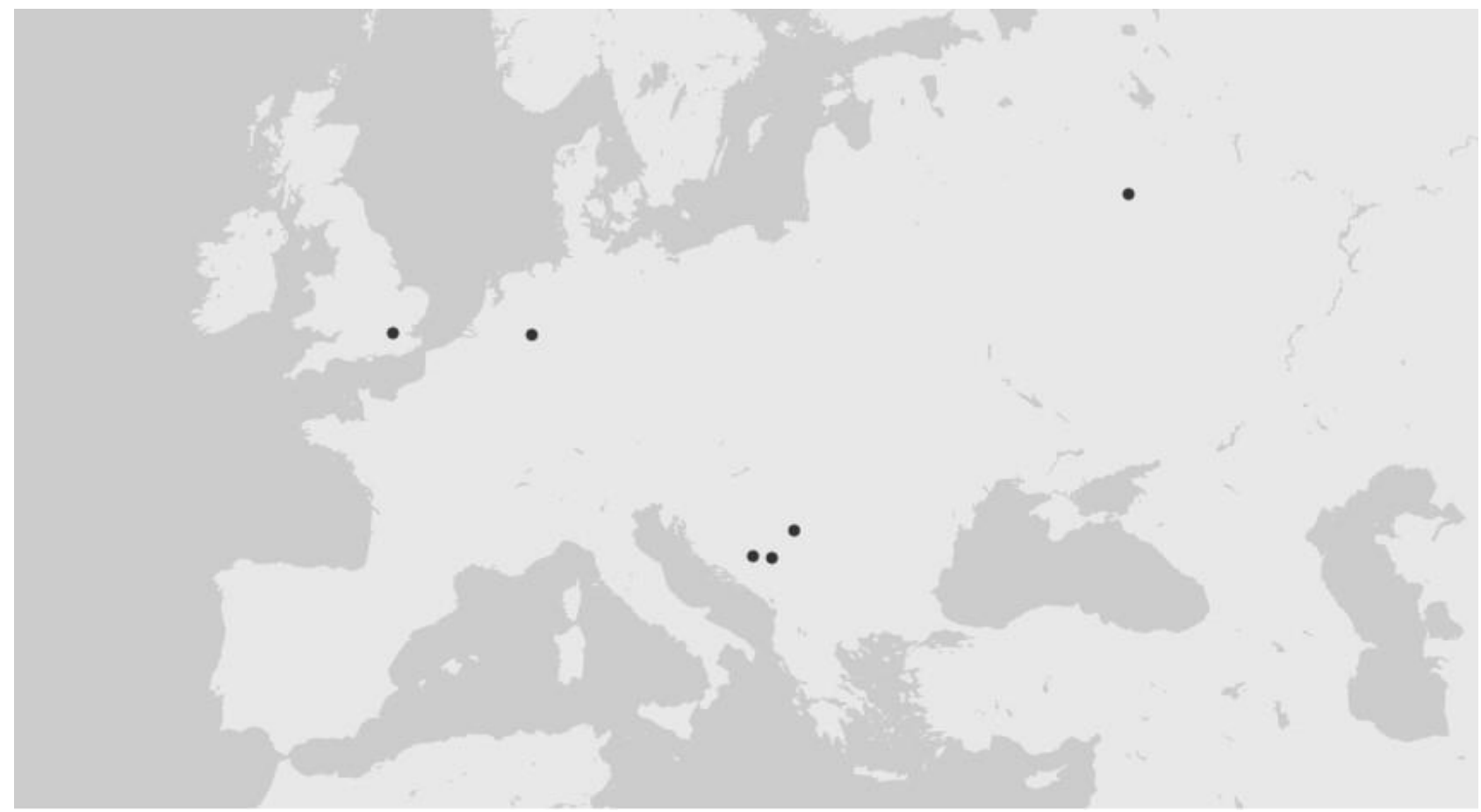

Map 4. Space in Clara Usón's and Saša Stanišić's novels

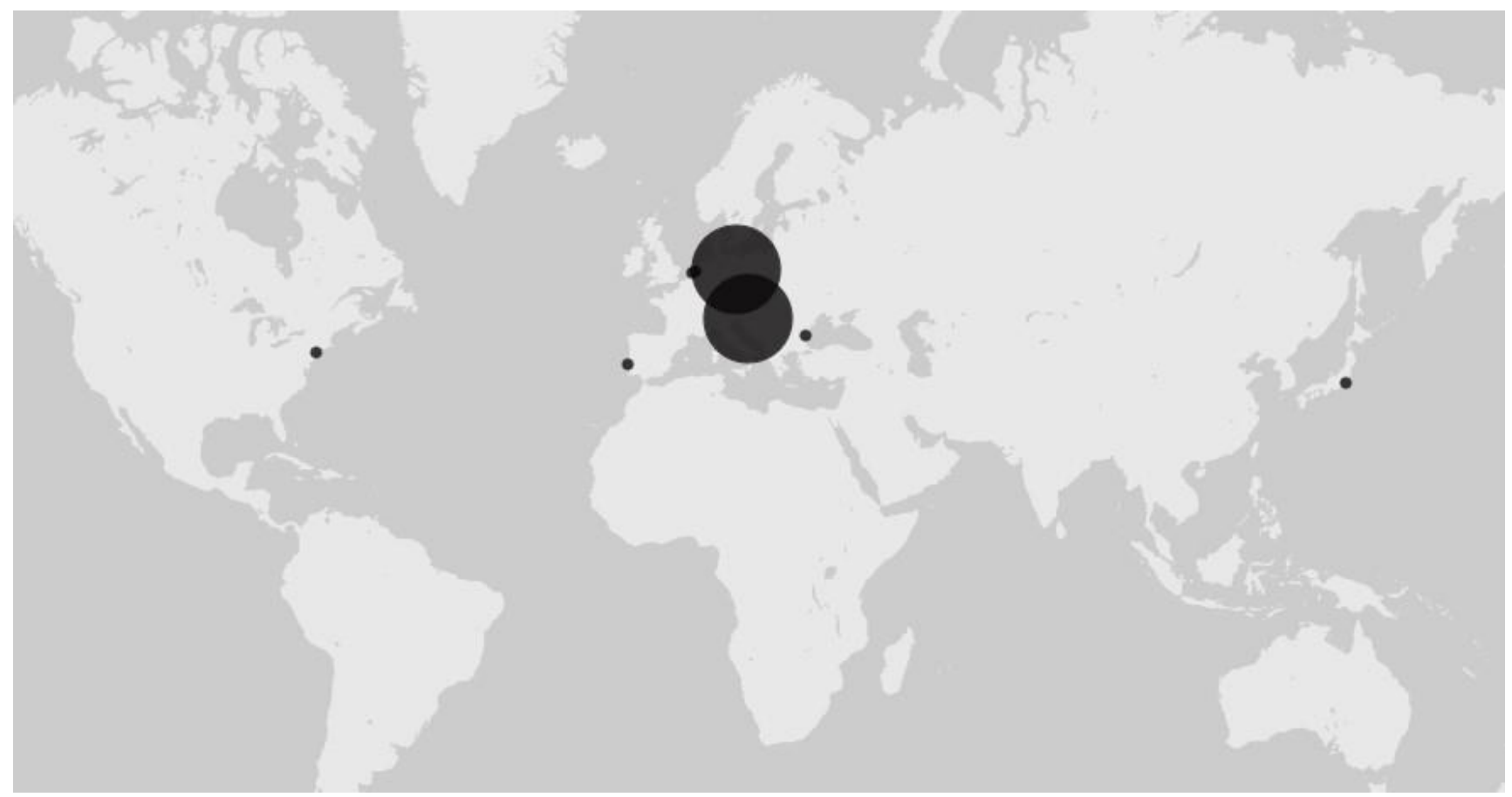

Map 5. Space in Dubravka Ugrešić's novels 


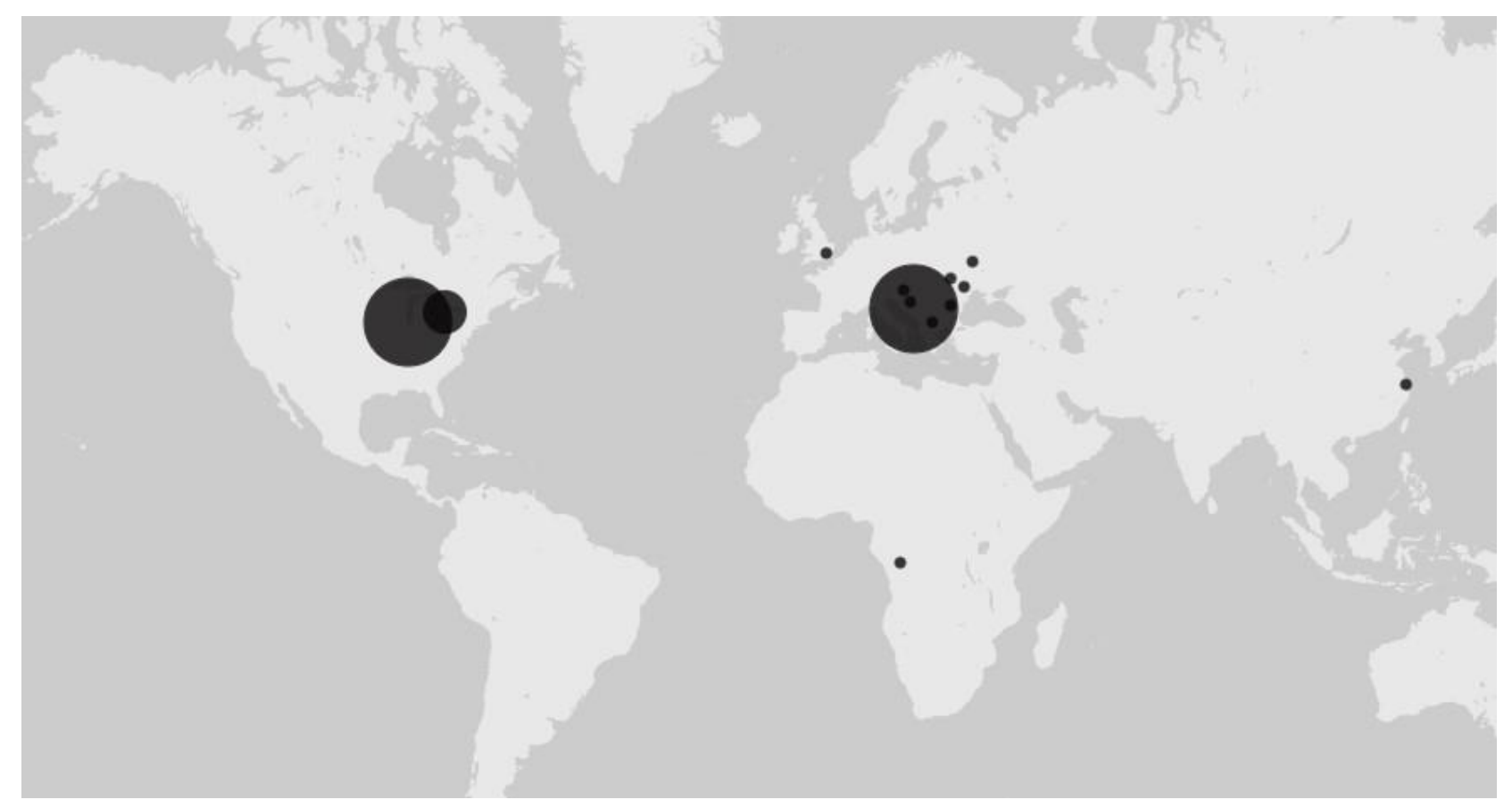

Map 6. Space in Aleksandar Hemon's books

However, besides the most frequent cities, there are another 6 settlements in Ugrešić's novels - Amsterdam, The Hague, Varna, New York, Lisbon, and Tokyo -, and 11 in Hemon's writings - Prnjavor, Murska Sobota, Kiev, Kishinev, Czernowitz, Bucharest, Hamilton, London, Shanghai, Ostia, Kinshasa. These cities are the ones to which the narrators have travelled to even if for a short period, or to which other main characters moved.

Map 5 reveals that the space represented in Ugrešić's novels includes cities from Eastern and Western Europe, North America, and Asia. Nonetheless, a serious reader of Ugrešić's books would say that the real number of places is definitely higher, proving the richness of cities and countries mentioned in the two novels analysed in this paper. For instance, three of the main cities from The Ministry of Pain are mentioned in the first pages of the novel: Berlin, Tokyo, Amsterdam. A few pages later, other cluster of spaces are mentioned: "Some Bosnian Muslims went to Turkey, Iran, Iraq, even as far as Pakistan; many rued the day. Some Bosnian Jews went to Israel" and "Those who scrambled got the best places: America, Canada" (Ugrešić 16). However, the next chapter of the novel draws the reader's attention from the world to ex-Yugoslavia. It is the high number of spatial references, along with this continuously shift from (ex)Yugoslavia to the world that gives the impression of a more extended geography. Nonetheless, the map shows that even if it does not include all the places mentioned in 
the novels, it still exceeds the basic home country-host country binary, proving that the spatial representation in Ugrešićs novels goes far beyond the ex-Yugoslav borders.

An even more extended geography defines Aleksandar Hemon's writings. Not only does the map include Kinshasa, but there is also a variety of spaces both within and without ex-Yugoslavia. Out of the 28 places, 13 are mentioned in Hemon's books, which means almost 50\% (Map 6). Furthermore, exactly like in Ugrešić's novels, the reference to the flows of migration supports the richness of the mentioned spaces. One example from Love and Obstacles demonstrates it: "we exchanged gossip about various people from Sarajevo: Sem was in D.C., Goran in Toronto; someone I knew but he could not remember was in New Zealand; someone I have never known was in South Africa" (Hemon 80).

I insisted on quoting from Hemon's and Ugrešić's writings because their focus on the migration flows is representative for the reshaping of the local. It is true that the local ex-Yugoslav space - weighs a lot in their books but it is so because of the "ex-". When it comes to post-Yugoslav space, they tend to represent it in terms of mobility. The Yugoslavs are everywhere, their home is the world or, as, Ugrešić writes, "Europe was teeming with former Yugos" (17). It is a space that cannot be grasped within clearly defined boundaries.

\section{Conclusions}

The first conclusion of this paper is that although the literature about former Yugoslavia is labelled as "exotic", as a literature that frames a local, peripheral space, its internal geography reveals a geo-cultural diversity. However, when the data is interpreted from a different angle, by approaching the literary texts individually, the literary works written by post-Yugoslav migrant writers, - who are classified according to the new states, as Serbian, Croatian, Bosnian -, are defined by a higher geographical diversity, whereas literary works written by non-Yugoslav writers tend to focus more if not even exclusively on the former Yugoslavia.

Secondly, the internal geography of the books analysed in this paper reinforces the hegemony of world literature. No matter how diversified the geography in the books written by peripheral authors is, they are still labelled as ethnic and/or immigrant authors. According to Apter, these labels "also cling like barnacles to their reception and afford constrictive stereotypes of identity" (98). Moreover, the categorization of these authors as ethnic and/or immigrant authors affects the 
reception of their texts, by reducing the geo-cultural diversity to only two types of spaces: the home country and the host country.

Thirdly, the uneven circulation and reception gives rise to various geographies of the literature about former Yugoslavia. While the Western public and market are more interested in the literary works that tackle simultaneously the war and the experience of migration, a peripheral market such as the Romanian one comprises also authors who may tackle only the war, or war and peripheral spaces. Therefore, considering all these findings, I state that the relation between the literature about former Yugoslavia and literary geography evinces that the literature about the former country can partially be read as world literature. Eventually, this partial presence and visibility on the world literary system is the result of the hegemonic character of the Western culture.

\section{References:}

Apter, Emily. The Translation Zone. Princeton University Press, 2006.

Damrosch, David. What Is World Literature?. Princeton University Press, 2002.

Durišin, Dionýz. Theory of Interliterary Process, translated by Jessie Kocmanová and Zdeněk Pištek, Slovak Academy of Sciences, 1989.

Even-Zohar, Itamar. "Polysystems Studies”. Poetics Today, 11.1/1990.

Hayot, Eric. "World Literature and Globalization". The Routledge Companion to World Literature, edited by Theo D’Haen, David Damrosch, and Djelal Kadir, Routledge, 2012: 223-231.

Hemon, Aleksandar. Love and Obstacles. Picador, 2009.

Juvan, Marko. "The Invisible Other? Slovenian Comparative Literature and Yugoslav Literature”. Jugoslovenska književnost: prošlost, sadašnjost $i$ budućnost jednog spornog pojma, edited by Adrijana Marčetić, Bojana Stojanović Pantović, Vladimir Zorić, Dunja Dušanić, 2019: 63-78.

Juvan, Marko. "From the Spatial Turn to GIS-Mapping of Literary Cultures". European Review 23.1/2015: 81-96.

Juvan, Marko. "Perspectivizing World Literature”. Literaturna misal, 61.1 (2018): 319.

Mitchell, Peta. "Literary Geography and the Digital: The Emergence of Neogeography". The Routledge Handbook of Literature and Space, edited by Robert T. Tally Jr, Routledge, 2017: 85-94. 
Moraru, Christian, Terian, Andrei. "Introduction: The Worlds of Romanian Literature and the Geopolitics of Reading”. Romanian Literature as World Literature, edited by Mircea Martin, Christian Moraru, and Andrei Terian, Bloomsbury Academic, 2018: 1-31.

Moretti, Franco. Atlas of the European Novel, 180o-19oo. Verso, 1999.

Moretti, Franco. “Conjectures on World Literature”. New Left Review 1/2000: 54-68.

Moretti, Franco. “More Conjectures”. New Left Review 20/2003: 73-81.

Obradović, Dragana. Writing the Yugoslav Wars: Literature, Postmodernism, and the Representation of Ethics. Toronto University Press, 2016.

Piatti, Barbara et al. "Mapping Literature: Towards a Geography of Fiction". Cartography and Art, edited by A. Lehn, G. Gartner, W. Cartwright, Springer, 2009: 179-194.

Pisac, Andrea. Trusted Tales: Creating Authenticity in Literary Representations from Ex-Yugoslavia. Unpublished PhD Thesis, University of London, 2010.

Thomsen, Mads Rosendahl. Mapping World Literature. International Canonization and Transnational Literature. Continuum, 2008.

Thompson, John B. Merchants of Culture: The Publishing Business in the TwentyFirst Century. Polity Press, 2011.

Ugrešić, Dubravka. The Ministry of Pain. Translated by Michael Heim. Harper Perennial, 2007.

Vermeulen, Pieter. "On World Literary Reading: Literature, the Market, and the Antinomies of Mobility". Institutions of World Literature: Writing, Translation, Markets, edited by Stefan Helgesson and Pieter Vermeulen, Routledge, 2016: 79-92.

Ung, Snejana. “The Literature about Former Yugoslavia in the Paradigm of World Literature”. Transilvania 5-6/2018: 38-42.

Vervaet, Stijn. "Ugrešić, Hemon, and the Paradoxes of Literary Cosmopolitanism: Or How to 'World' (Post-)Yugoslav Literature in the Age of Globalization". Komparativna književnost: teorïa, tumačenja, perspektive. Encompassing Comparative Literature: Theory, Interpretation, Perspectives, edited by Adrijana Marčetić, Zorica Bečanović-Nikolić, Vesna Elez, 2016: 161-169.

Wachtel, Andrew Baruch. Making a Nation, Breaking a Nation: Literature and Cultural Politics in Yugoslavia. Stanford University Press, 1998. 
METACRITIC JOURNAL FOR COMPARATIVE STUDIES AND THEORY 6.1

Wachtel, Andrew. “The Legacy of Danilo Kiš in Post-Yugoslav Literature”. The Slavic and East European Journal 50.1/2006: 135-149.

Walkowitz, Rebecca L. Born Translated: The Contemporary Novel in an Age of World Literature. Columbia University Press, 2015. 